\title{
CORRESPONDENCE
}

Correspondents are asked to be brief

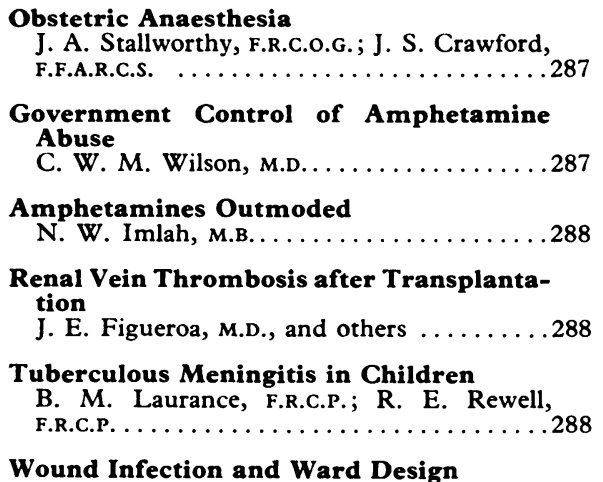

I. G. Schraibman
Abnormal Bile or Faulty Gall Bladder?

K. W. Heaton, M.D. ..............289

Resuscitation Too Late

Consultant Physician ...............289

Indications for Hysterectomy

J. K. McCollum, F.R.C.S.ED .

Metformin and Stanozolol in Blood
Fibrinolytic Activity

I. S. Menon, M.B. . . . . . . . . . . . 289

Mechanisms in Pernicious Anaemia

F. S. Mooney, F.R.C.PATH., and J. G.

Heathcote, PH.D.; T. E. Parry, F.R.C.PATH. . 290

Malaria in Britain

J. Mackay-Dick, F.R.C.P. ED. . . . . . . . .291
Few Applicants for Hospital Junior Posts

E. A. Burkitt, D.P.M. ................291

Fees for Radiological Examinations

M. Goldman, M.B., D.M.R.D., and J. Winter,

M.D., D.M.R..................291

Regional Registrar Committees

"D. Macduff"

Salmon and Cogwheel

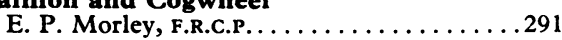

Vocational Training for General Practice

J. Duguid, M.B. . . . . . . . . . . . . . ...292

Accident Emergency Services

R. Snook, M.B.; J. Kotowski, M.B.; J. E.

Crockett, M.R.C.s. . . . . . . . . . . . . 292

\section{Obstetric Anaesthesia}

SIR,- The labour wards and theatres of an obstetric department work as hard by night as by day. If a unit of sufficient size, "more than 2,000 deliveries . . . annually" (Dr. Gordon Taylor, 9 January, p. 101) justified the appointment of an anaesthetist "without other duties" it would be necessary to appoint at least three to provide a 24-hour service. This would obviously be impossible as well as unnecessary.

But the fact that there is not an obstetric anaesthetist with no other duties does not make it "impossible to provide a 24-hour regional analgesic service." Every obstetric registrar or lecturer on appointment can learn, and quickly master, the caudal technique. In this way an efficient service is available. Over 6,000 patients at Oxford have cause to be grateful for caudal analgesia provided in this way, and many visitors have come to learn the technique prior to practising it and teaching it in departments elsewhere.

When the ideal to which Dr. Gordon Taylor referred is not obtainable an effective interim service is within the reach of all.-I am, etc.,

Nuffield Department of Obstetrics
and Gynaecology,

Churchill Hospital, Oxford

SIR,-May I comment on Dr. Gordon Taylor's research into this subject (9 January, p. 101)? The extensive survey, which was conducted at the request of the Obstetric Anaesthetists' Association, confirms the general impression held by many of us. The staffing of obstetric units in the U.K. by competent anaesthetists and the supervision of trainee anaesthetists in this field are deplorably deficient. Until proved otherwise, it must be considered a major factor contributing to the large number of maternal deaths associated with anaesthesia. The effect of the deficiency on neonatal morbidity and mortality is at the present incalculable, but it is possibly significant to note Dr. Taylor's finding that in over half the hospitals he surveyed an anaesthetist was first on-call for neonatal resuscitation. The less dramatic problems of adequacy of safe relief from pain in labour also come well within the province of the anaesthetist nowadays.

That the complex, frequently urgent, challenges of anaesthesia, resuscitation, and adequate analgesia are left virtually exclusively in the hands of unsupervised, relatively untrained, and frequently harassed junior anaesthetists is surely an intolerable situation: unfair to trainees as well as to the patients. The situation is summarized in Dr. Taylor's finding that in 344 hospitals the total consultant anaesthetist sessions nominally devoted to obstetrics numbered 222, and in 242 of these hospitals there was no such official commitment.

The Obstetric Anaesthetists' Association urges that consultations between representatives of all the professional bodies concerned be started without delay, with the objective of remedying the situation.-I am, etc.,

\section{J. Selwyn Crawford}

Birmingham Maternity Hospital,

Birmingham 15
Drugs Bill published. ${ }^{3}$ In contrast, control of the import, distribution, and sale of amphetamine preparations was imposed by the Irish Government at the end of 1969 (Medical Preparations (Control of Amphetamines) Regulations, 1969). This provided an opportunity to assess on a national scale the effectiveness of the type of control recommended by the B.M.A. Working Party.

Urine samples from boys admitted to a custodial establishment in Ireland during the last quarter of 1969 and the first quarter of 1970 were analysed by gas liquid chromatography for the presence of amphetamine." Amphetamine was detected in the urine of $11.4 \%$ of the first sample of 123 boys, but in only one of 171 samples of urine in the second period. Similar tests have been done on boys in English remand homes on several occasions ${ }^{5-7}$ since 1965 (Table). The percentage of positive samoles fell from $17 \cdot 2 \%$ in 1965 to $2.0 \%$ in 1969.

Amphetamine abuse had reached its peak incidence in Britain in 1965. Even though the Drugs (Prevention of Misuse) Act, 1965, probably did not give effective powers for controlling the abuse of amphetamines, ${ }^{8}$ growing public alarm discouraged their availability. It is therefore not surprising that the number of boys in English remand homes with amphetamine in the urine fell by $88 \%$ between 1964 and 1969. However, the fact that amphetamine was still detected in $2 \%$ of the samples four years after the peak incidence had been reached shows that public discouragement and voluntary restraint of amphetamine availability are ineffective controls and exert their influence relatively slowly.

Amphetamine abuse came to Ireland later than elsewhere in Britain.' The finding of $11.4 \%$ in the Irish samples at the end of 1969 corresponds to the relatively high value occurring in London when amphetamine abuse was approaching its peak. The percentage of positive samples in Ireland might well have exceeded the level reached in the last quarter of 1969 had the timely prohibition on the distribution and sale of amphetamine preparations not been intro-
SIR,-The B.M.A. Working Party on where this voluntary control was put into Amphetamine Preparations recomended effect, it succeeded in preventing any rise in their control by government regulation, ${ }^{1}$ but amphetamine abuse. ${ }^{2}$ Not until March 1970 the British Government decided that control should be on a voluntary basis. In Ipswich, was the urgent need for government control recognized and the proposed Misuse of 
Analysis of Surveys on Urinary Samples from Boys in Custodial Establishments for Presence of Amphetamine

\begin{tabular}{|c|c|c|c|c|c|c|c|}
\hline \multicolumn{4}{|c|}{ Period } & Place & Age Range & o Positive & Investigator \\
\hline $\begin{array}{l}\text { Jan-June } 1964 \ldots \\
\text { May-May 1967-8 } \\
\text { Oct-Sept 1968-9 } \\
\text { Oct-Dec } 1969 \text {... } \\
\text { Jan-April } 1970 \ldots\end{array}$ & $\begin{array}{l}\cdots \\
\because \\
\cdots\end{array}$ & $\begin{array}{l}\cdots \\
\because \\
\cdots \\
\cdots\end{array}$ & $\begin{array}{l}. \\
\therefore \\
\cdots\end{array}$ & $\begin{array}{l}\text { London } \\
\text { London } \\
\text { Manchester } \\
\text { Ireland } \\
\text { Ireland }\end{array}$ & $\begin{array}{r}12-17 \\
<21 \\
13-16 \\
14-18 \\
14-18\end{array}$ & $\begin{array}{r}17 \cdot 2 \\
6.9 \\
2.0 \\
11.4 \\
0.6\end{array}$ & $\begin{array}{l}\text { Scott \& Willcox } \\
\text { Cockett \& Marks } \\
\text { Lancaster \& Rockley } \\
\text { Wilson, 1970 } \\
\text { Wilson, } 1970\end{array}$ \\
\hline
\end{tabular}

duced by the Irish Government. It can therefore be concluded that control of the abuse of specific drugs by government regulation is effective if introduced sufficiently early.-I am, etc.,

Cedric W. M. Wilson

\section{Department of Pharmacology, \\ University of Dublin,}

1 Report of the Working Party on Control of Amphetamine Prepar, 1968, 4, 572 .

2 Wells, F. O., British Medical foumal, 1970, 2

Byrne, P. J., Foran, K., Miller, J. T., and Wilson 1971, January.

1971, January.
Scott, P. D., and Willcox, D. R. C., British
fournal of Addiction, 1965, 61, 9. Fournal of Addiction, 1965, 61, 9.
Cockett, R., and Marks, V., British foumal of
Phychiatry, 1969, 115, 1203. 7 Lancaster, B., and Rockley, G. J., British Yournal of Psych:atry, 1970 , 116,349 .
Connell, P. H., in Pharmacological and Epidem-
iological Aspects of Adolescent Drug Dependence, ed. C. W. M. Wilson, p. 41, Oxford, Pergamon Press, 1968 . in Pharmacological and Epidemiological Aspects of Adolescent Drus Oxford, Pergamon Press, 1968. 3 Misuse of Drugs Bill, 1970. London, H.M.S.O

Tuberculous Meningitis in Children

SIR,-YYour leading article (2 January, p. 1) is an admirable survey of the clinical features of tuberculous meningitis. The section on treatment was valuable also but, Sir, you mention that this is nowadays principally a disease of developing countries. Alas, the coffers for their health services are small so that it is surely impractical to advocate treatment with para-aminobenzoic acid which in addition to being unpleasant to take and having so many gastrointestinal side effects is so expensive. Thiacetazone is ten times cheaper and as efficacious. ${ }^{1}$ Like all drugs, the dose of thiacetazone needs to be adjusted to weight, but with this proviso side effects are uncommon-at least in East Africa. Admittedly this lack of toxicity does not necessarily apply to other countries but it is likely to be so.- I am, etc.

\section{B. M. LauRance} Queen Elizabeth Hospital for Children,
London E.2

\section{Amphetamines Outmoded}

SIR,-I am surprised to see that Dr. H. J. S. Matthew (26 December, p. 801) regards diethylpropion as being in the same category as phenmetrazine with regard to its capabilities for producing addiction and of being abused. Diethylpropion in contrast to phenmetrazine has been categorized " $A$ " by the Magregor Committee, and in addition is excluded from the provisions of the Drugs (Prevention of Misuse) Act 1964, and the schedules of the Misuse of Drugs Bill. The only other appetite suppressant to receive such a clean bill of health is fenfluramine, a compound which because of its complex

psychomimetic properties itself has a potential for abuse.

The balance of current available information suggests that there are only two drugsnamely, diethylpropion and fenfluraminewhich at the moment can be prescribed with relative confidence to assist in the reduction of weight of obese individuals. I am, etc.,

All Saints Hospital

NORMAN W. IMLAH

Birmingham 18

1 Imlah. N. W., British Medical fournal, 1970, 2 173.

\section{Renal Vein Thrombosis after Transplantation}

SIR,-Since Mr. S. D. Clarke and his colleagues (17 January, p. 154) comment that there are surprisingly few references to thrombosis of the renal vein as a complication of transplantation we wish to report such a case.

Ten hours after bilateral nephrectomy and renal transplanation a 28-year-old male patient developed a large perinephric haematoma. It was surgically evacuated with control of shock and return of urinary output. On the morning of the fourth postoperative day the patient voided blood-tinged urine. Several hours later he voided a large blood clot and became anuric. He complained of pain in the area of the allograft and in the right leg. The right thigh was becoming oedematous. An intravenous urogram showed no function. A renal arteriogram showed patent renal arteries with tapering and poor perfusion of the cortex. These changes were thought to be compatible with renal vein thrombosis.

Emergency surgery revealed thrombosis of the donor renal vein. The allograft was engorged and the capsule was bulging. Thrombectomy of the renal vein was performed. To avoid kinking of the venous anastomosis an end-to-end anastomosis between the renal vein and cephalad end of the severed external iliac vein was necessary. The caudal end of the external iliac vein was ligated. A renal biopsy revealed severe tubular cell degeneration. The arterial circulation was interrupted for twenty minutes. The estimated time from renal vein occlusion to re-establishment of blood flow was $7 \frac{1}{2}$ hours. A satisfactory course followed and the patient was discharged with no dietary restrictions and a creatinine clearance of $20 \mathrm{ml} / \mathrm{min}$.

The patient was followed at another institution after discharge but his general condition did not improve. The allograft functioned until his death $4 \frac{1}{2}$ months later of unknown causes. A postmortem examination of the renal allograft showed severe interstitial fibrosis but the renal vessels were patent.

In our patient oliguria persisted for 14 days following thrombectomy. This period of oliguria was due to acute tubular necrosis resulting from ischaemia produced by both the renal venous thrombus and the interruption of circulation necessitated for its removal. This period was followed by typical diuretic phase with recovery of function. However, the renal function never returned to normal. This fact, in the absence of initial histological evidence of rejection, sug gested that the renal allograft had suffered ischaemic damage even before the episode of occlusion, perhaps as a result of shock due to perirenal haemorrhage which occurred only six hours after transplantation. The ischaemic damage was further aggravated by the renal venous thrombosis and resulted in irreversible interstitial fibrosis and tubular atrophy.

Although anticoagulant therapy has been advocated for treatment of renal vein throm bosis, ${ }^{1}$ we did not use anticoagulants because of the danger of postoperative bleeding from the allograft and the surgical wound.

We agree with Mr. Clarke and his colleagues that early suspicion and detection of venous thrombosis after transplantation will determine the degree of success after surgical correction.-We are, etc.,

Julio E. Figueroa LAURENCE $M$. CORTEZ Paul T. DeCam JOHN L. OCHSNER

Alton Ochsner Medical Foundation

New Orleans, Louisiana, U.S.A.

Pollak, V. E., Pirani, C. L., Seskind, C., and 65, 1056.
SIR,-The leading article on "Tuberculous Meningitis" (2 January, p. 1) omits one important pitfall in the findings in the cerebrospinal fluid. Especially in early cases of rather acute onset the cerebrospinal fluid may contain numerous polymorphs-this before chemical changes become apparent. There are, however, no bacteria to be found in stained films, nor do any grow in ordinary cultures. A similar appearance can be produced when pus is approaching the meninges from any source, such as osteomyelitis of a vertebra or a temporal lobe abscess. Those of us who are old enough to have had some experience of tuberculous meningitis have seen cases misdiagnosed on this account. To the experienced the clinical picture will give the answer. Treatment must be started early if sequelae are to be avoided, and there is no time to wait for results or ordinary culture or even of examination for tubercle bacilli, which may itself lead to at least a day's delay.-I am, etc.,

\section{R. E. REWELI}

Department of Patholozy,

The Women's Hospital,

Liverpool 8

\section{Wound Infection and Ward Design}

SIR,-I was most interested in the thorough and lucidly presented survey of postoperative wound infection in relation to ward design by Dr. H. G. Smylie and others (9 January, p. 67), and Mr. A. I. G. Davidson and others (p. 72). It would seem logical to establish surgical wards of the design that they have recently used, but proving their effectiveness in terms of wound infection is apparently a different matter. In relation to the definition of wound sepsis most workers seem to include a category of minor sepsis; this is, however surely irrelevant at best and a red herring at worst. The only criterion of important infection is discharge of pus through the main wound, because this delays the
Lloyd, A. V. C., East Africa Medical fournal,
1969, 46, 481. 